\title{
Strengthening Local Institution to Improve Phytoremediation of Mangrove Forest Based on Co-Management: Case Study in Wonorejo, Surabaya, East Java, Indonesia
}

\author{
Rudianto \\ Head of Exploration of Fisheries and Marine Resources Laboratory \\ Faculty of Fisheries and Marine Science \\ Brawijaya University \\ Malang \\ Corresponding email: haji_rudianto@yahoo.com
}

\begin{abstract}
The role of local institutions in carrying out the restoration of mangrove forests in the city of Surabaya is required a very close cooperation among all the stakeholders involved. To achieve the required success, is needed co-management approach based on community participation. The mangrove forest in Wonorejo suffers from degradation because of anthropogenic factors, even though mangrove forests serve to row as a protection from coastal erosion, as a stabilizer shoreline, filter and trap pollutants, as the breeding ground, as well as the area of foraging various types of fish and shrimp. The data shown that the extent of mangrove areas Wonorejo area is 480 hectares or $0.74 \%$ of the area of the city of Surabaya. In 2012, the mangrove areas were damaged area of 288 hectares from 480 hectares. The cause of damaged mangroves for the construction of a residential area is very intensively every years. The water's quality shown that there is contamination due to domestic waste. So that turbidity, suspended solids, phosphate, nitrate and total coliform have exceeded environmental quality standards. The environmental impact is a reduction in marine catches by fishermen. It is estimated that fish catch is only reach $25-30 \mathrm{~kg}$ per day, whereas five years ago marine catches reached $80-90 \mathrm{~kg}$ per day. Restoring mangrove degradation and its phytoremediation capability to absorb water pollution is required not only technical factors for improving mangrove condition, but also the most important is the institutional factors.
\end{abstract}

Keywords-Co-management, local institution, partial least square, analytical hierarchy process

\section{INTRODUCTION}

As we all know that mangrove forests have ecological and economic functions. As a function of ecology, mangrove is vital to marine life such as fish both pelagic and demersal, shellfish both crustaceans and mollusks, kind echinoderms, and sponges. Mangrove function is a function of spawning, nursery, and feeding. While the economic functions of various types of mangrove in commercial scale can be used as: (a) chips is mainly Rhizophora spp and Bruguiera spp, (b) board industry and plywood are especially the type Bruguiera spp and heritiera littoralis, (c) scalfold is especially Rhizophora apiculata, Bruguiera spp and Ceriops spp, and (d) of firewood and charcoal of high quality is mainly of Rhizophora spp.

Given the importance of the mangrove function, humans forget to conserve and even perform irrational utilization patterns. Many mangrove forests are cleared for shrimp farming, construction of new housing clusters, the establishment of shops and even converted to the commercial area. Wonorejo in the region, an area that previously had extensive mangrove 480 ha in 2008, currently has shrunk to 240 hectares in 2012 (Adiwijaya, 2012). The impact caused by the depreciation of the mangrove catches are reduced by 25 to $30 \mathrm{Kg}$ per day, whereas five years before reaching the catch amounted to $80-90 \mathrm{~kg}$ per day. In addition to the decline in production, the fishermen are also complaints more difficulty in getting the kind of results that diverse marine catches. At this time fishermen only get the crab and swordfish as the primary catch. While the other catches as grouper, pottery increasingly difficult to obtain.

Protection of mangrove areas in Wonorejo been set in local legislation of Surabaya No. 3 of 2007 on Spatial Planning Surabaya and Surabaya City RTRW reviewed that handling the east coast of Surabaya directed to the protection and preservation of ecosystems, where one of the development policy of the protected area as a tourist area of research is directed through the Mangrove Information Center. According to the Environment Agency of Surabaya (2012) stated that the eastern coastal area of Surabaya is generally a muddy beach and dealing directly with the Madura Strait. Whereas, the mainland was largely dominated by tourism, fishermen, fisheries and mangrove forests. While the waters territorial is limited to activities of fisheries and marine tourism activities groove, shooting training zone and a sea mine. It is further mentioned by Environmental Agency (2012) that the decline of mangrove land in such region caused by land 
conversion. However, over the function that occur do not result in significant changes in the land that the ratio of the total area of mangrove in 2010 and 2011 inconspicuous. According to Wijanarko (2006) if the government of Surabaya really committed to protect and to control the use of the beach area wisely, then the community participation in the planning and management of green open space needs to be optimized by using the approach of co-management. This approach to fill gaps in state-based and community-based approach.

According to Mikkelsen (2003) mentioned that approach of community participation requires local institutions and communities. Such participation was given the right to design the program, including thinking together about what is needed to be repaired and to be restored. Participation is defined as the amount of funds that can be saved or funds that can be provided as donations or contributions to the community government projects. Community participation is defined as extensive involvement in any development process, starting from: 1). Involvement in the identification of problems, which the community together with the planners or policy authority to identify problems, identify opportunities, potential and barriers. $2)$. The planning process, where communities are actively involved in the preparation of plans and strategies based on the results previous identification. 3). Implementation of development projects. 4). Evaluation, namely the community involved to assess development outcomes that have been made, whether the construction of benefit to society or vice versa communities disadvantaged by the process that has been done. 5). Monitoring and 6). Mitigation, which involved in measuring and reducing the negative impacts caused by the project that is being implemented.

Co-management approach according to Wells, et al (1992) that all stakeholders were given the same opportunity to be actively involved in the management of mangrove forest destruction. This is intended to ensure that the commitment and participation and to accommodate knowledge, aspirations and experience in the management of mangrove. Local institutions are comprising of all stakeholders trying to keep the coastal waters in the village Wonorejo potentially polluted by domestic waste (derived from household activities) can be managed with centralized wastewater treatment. It is urgent to do because based on data found in marine waters and the surrounding area Wonorejo (Gunung Anyar) has high levels of turbidity, suspended solids, phosphate, nitrate and total coliform that have exceeded environmental quality standards. Domestic waste potentially contaminate the waters flowing down to the eastern coast of Surabaya. Domestic pollution can cause death of aquatic fauna due to bioaccumulation of domestic waste in the body of the biota.

According to Wahwakhi (2015) stated that in order to tackle water pollution in coastal waters in Wonorejo, especially in the form of heavy metals $\mathrm{Pb}$ pollution, the role of mangroves is very important, because it has a capability to absorb pollution via mangrove phytoremediation. In general, mangrove vegetation has the ability to accumulate the metal in his body. Mangrove species that are able to absorb heavy metals are Avicennia alba. Therefore the purpose of this study is to enhance the role of local institute to improve the ability of Avicenniaalba absorb heavy metals through good governance approach.

\section{METHOD}

The time required to conduct this research requires a period of 2 (two) months from June to July 2015. The procedure is done with the design study of descriptive research, using qualitative and quantitative techniques. Those are process that tries to gain a better understanding of the complexity tackling the problem $\mathrm{Pb}$ as heavy metal pollution in coastal waters Wonorejo. Quantitative method performed using Partial Least Square (PLS) followed by using qualitative methods of Analytical Hierarchy Process (AHP). While the data used are primary data obtained from the questionnaire deployment of 30 respondents consisting of mangrove forest community of 15 people, the management of mangrove forests as much as 2 people, elements of government officials as many as five people, tourists 8 people. The substance of interviews targeting is the interaction between stakeholders and in particular to obtain information about the rehabilitation of mangrove forests to enhance the ability of mangrove phytoremediation. With the rehabilitation of mangrove forests correctly by stakeholders, is expected to increase the ability of mangrove phytoremediation. Increasing phytoremediation by mangrove means to repair damage to mangrove forests. The expected impact of the increasing in mangrove phytoremediation is the reduction of water pollution. Furthermore, the reduction of pollution habitat conditions of life will be restored. Recovery of aquatic habitats will affect production increase reef fish catches.

Using Method of PLS will produce structural equation modeling made possible by the relatively small sample size and needed multivariate normal assumption. (Jaya et al., 2008). The following conceptual structural model image enhancement capabilities mangrove phytoremediation based on comanagement as described as follows: 


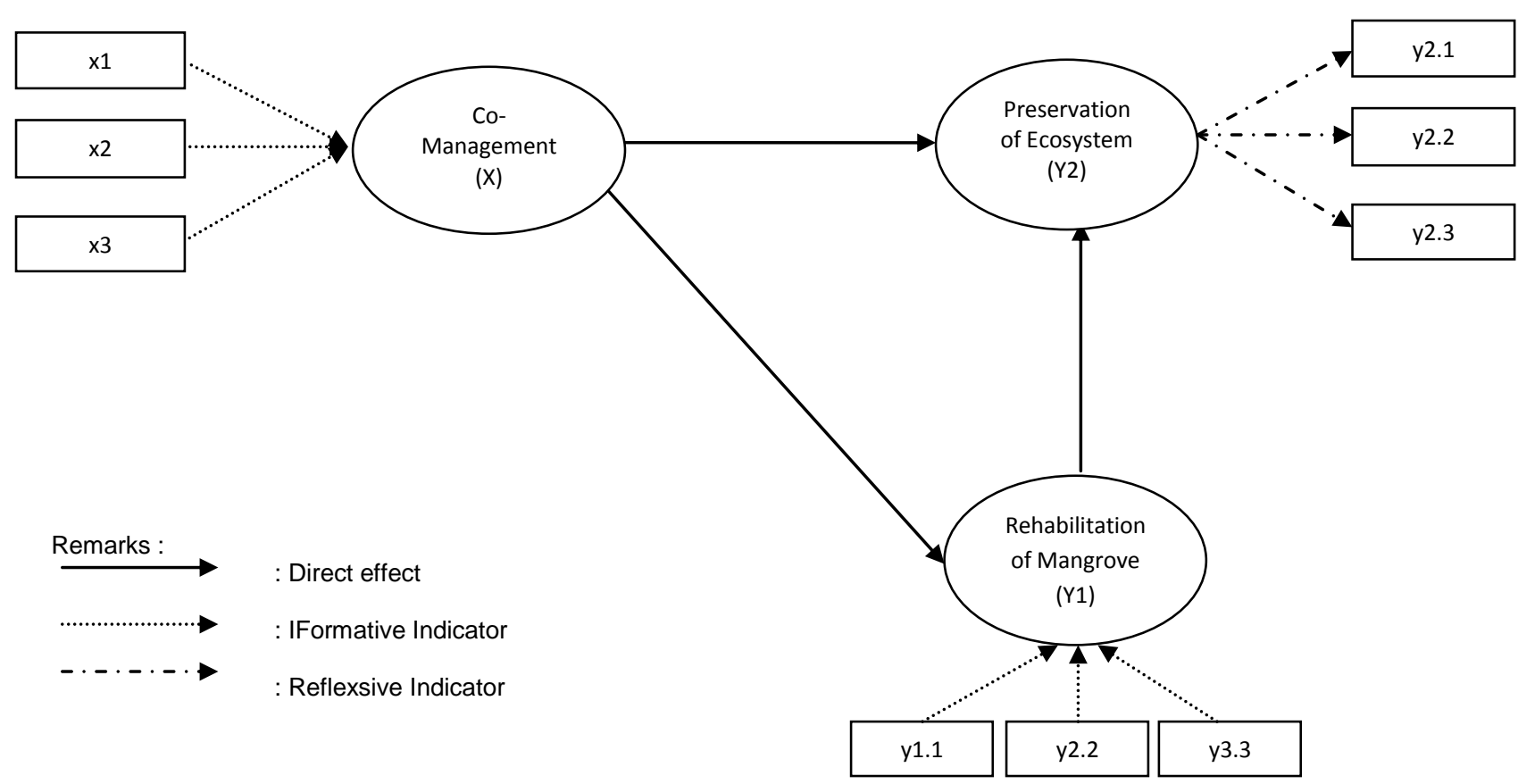

Fig. 1. Conceptual Structural Model

Meanwhile, AHP is a decision support models developed by Thomas L. Saaty (1993). Models supporting this decision will spell trouble multi-factor or multi-criteria complex into a hierarchy, according to Saaty (1993), the hierarchy is defined as a representation of a complex problem in a structure of multi-level where the first level is a goal, followed by level factors, criteria, sub-criteria, and so on down to the last level of the alternatives.

\section{RESULTS AND DISCUSSION}

Linearity testing assumptions must be met before the model is interpreted. The assumption of linearity is said to be fulfilled, if the probability value of less than 0.05 linear model or a significant linear model. Based on the assumption of linearity test results to the linear model the probability value less than 0.05 . Thus, it can be said that the assumption of linearity structural model has been fulfilled. Goodness of Fit Testing Structural Model (Inner Model) on the inner predictive model using valuerelevance $(\mathrm{Q} 2)$. Here are the results of calculation of predictive relevance $(\mathrm{Q} 2)$ structural model is as follows:

TABLE I. $\mathrm{R}^{2}$ and $\mathrm{Q}^{2}$ STRUCTURAL Model

\begin{tabular}{|c|c|c|}
\hline Structural Model & $\mathrm{R}^{2}$ & $\mathrm{Q}^{2}$ \\
\hline Model 1 & 0,545 & \multirow{2}{*}{0,913} \\
\cline { 1 - 2 } Model 2 & 0,809 & \\
\hline
\end{tabular}

The calculation result shows that the predictive valuerelevance (Q2) of 0.913 or $91.3 \%$. Relevance predictive value of $91.3 \%$ indicates that the diversity of data that can be explained by the model amounted to $91.3 \%$. While, the remaining $8.7 \%$ is explained by other variables (which is not contained in the model) and error. Testing the validity and reliability of the model can be done by calculating the Average Variance Extracted (AVE). Structural model is said to be valid if obtained AVE values> 0.5 . While, the reliability of the structural model can be measured from the composite reliability and Cronbach Alpha coefficients. Structural model said to be reliable if the obtained composite reliability coefficient $>0.7$ and Cronbach's alpha coefficient $>0.6$ (Jogiyanto and Abdillah, 2009). Here are the results of testing the validity and reliability of the structural mode.

TABLE 2. Testing The VALIDITY And Reliability Model

\begin{tabular}{|c|c|c|c|}
\hline Variable & AVE & $\begin{array}{c}\text { Composite } \\
\text { Reliability }\end{array}$ & $\begin{array}{c}\text { Cronbachs } \\
\text { Alpha }\end{array}$ \\
\hline X (Co-Management) & - & - & - \\
\hline $\begin{array}{c}\text { Y1 (Mangrove } \\
\text { Rehabilitation) }\end{array}$ & - & - & - \\
\hline $\begin{array}{c}\text { Y2 (Ekosystem } \\
\text { Preservation) }\end{array}$ & 0.945 & 0.981 & 0.971 \\
\hline
\end{tabular}

Based on Table 2 above, it can be explained that the AVE value of more than 0.70 , composite reliability and Cronbach 
Alpha for each variable is greater than 0.70 and 0.60 . So, from this test it can be concluded that the indicators of a latent variable constituent has good internal consistency.

Structural Model Testing Results (Inner Model) is done by testing the inner model (structural model) is basically testing the hypothesis. Based on the results of the analysis by using statistical software Smart PLS, Model Inner obtained test results as follows:
TABLE 3. The Results Of Testing FordiRect EFFects In INNER Model

\begin{tabular}{|l|c|c|c|}
\hline \multicolumn{1}{|c|}{ Direct Effect } & PathCoeficient & T-Statistics & P-Values \\
\hline $\begin{array}{l}\text { X (Co-Management) -> Y1 } \\
\text { (Rehabilitation of Mangrove) }\end{array}$ & 0.738 & 7.288 & $0.000^{* *}$ \\
\hline $\begin{array}{l}\text { X (Co-Management) -> Y2 } \\
\text { (Ecosystem Preservations) }\end{array}$ & 0.677 & 2.975 & $0.003^{* *}$ \\
\hline $\begin{array}{l}\text { Y1 (Rehabilitation og } \\
\text { Mangrove) -> Y2 (Preservation } \\
\text { of Ecosystem) }\end{array}$ & 0.275 & 1.182 & $0.238^{\text {ns }}$ \\
\hline
\end{tabular}

Results of testing the hypothesis states that the path coefficient can also be seen in the structural model as follows .:

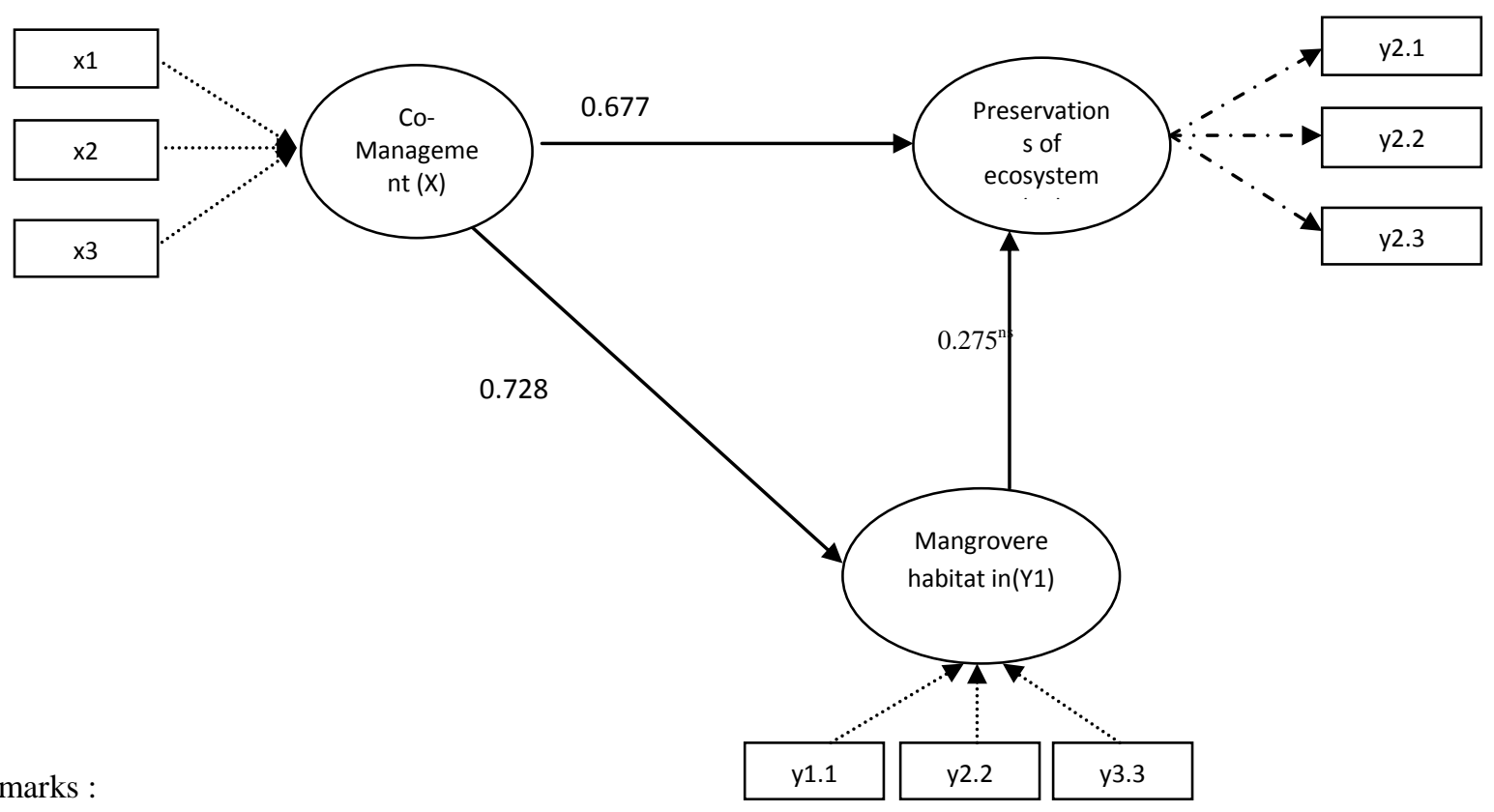

ns: non-significant

Fig. 2. Structural ModelAs The Results of Inner Model Hypothesis

From the pictures and the table above shows that on the test model of the effect of variable inner Co-Management (X) to the Mangrove Rehabilitation (Y1), path coefficients obtained for 0728 with a p-value of 0.000 . P-value less than $0.05(\mathrm{P}<0.05)$ showed that the co-Management provides significant direct effect on mangrove rehabilitation. Likewise, in co-management test variable $(\mathrm{X})$ on the preservation of the ecosystem (Y2), path coefficients obtained for 0677 with a p-value of 0.003 . P-value less than $0.05(\mathrm{P}<0.05)$ showed that the co-management provide significant direct effect on the preservation of the ecosystem. A positive coefficient indicates that the more positive the better the quality of co-management have an impact on the sustainability of ecosystems. While the effect of variable Mangrove Rehabilitation (Y1) to the Ecosystem Sustainability (Y2) has path coefficients
0.275 with a p-value of 0.238 . P-value is more than $0.05(\mathrm{p}>$ 0.05 ) shows that the rehabilitation of mangrove forests do not provide significant direct effect on the preservation of the ecosystem. This happens because the rehabilitation of mangroves in Wonorejo not been implemented optimally. There are still many people who use excessive mangrove trees and even less likely to be responsible. In addition, the supervision of the government is still very minimal. Thus, the rehabilitation process is not able to run optimally and there is no improvement the sustainability of the ecosystem.

Mangrove ecosystem conservation strategy based on "good governance" are arranged in order of priority. Priority parties that play a role in addressing the problems in the coastal mangrove 
ecosystem Wonorejo focused on three alternatives of stakeholders, namely the government, public, and private sectors. The third alternative is selected as an alternative to the consideration of the relationship in terms of planning, implementation, and supervision of the preservation of the mangrove ecosystem. Based on the results of research in the field, it was revealed that the public rarely directly involved in the program launched by the government, especially in mangrove rehabilitation. Supervision in the utilization of mangrove forests was also still a lot of violations, such as excessive felling mangrove trees for firewood and materials for buildings. Society consciousness in protecting the environment is also lacking. Therefore, it is necessary to integrate the involvement of government, private and community in restoration and conservation of mangrove ecosystems in Wonorejo Coast region. Setting priorities based on criteria that are arranged in a hierarchy as follows:

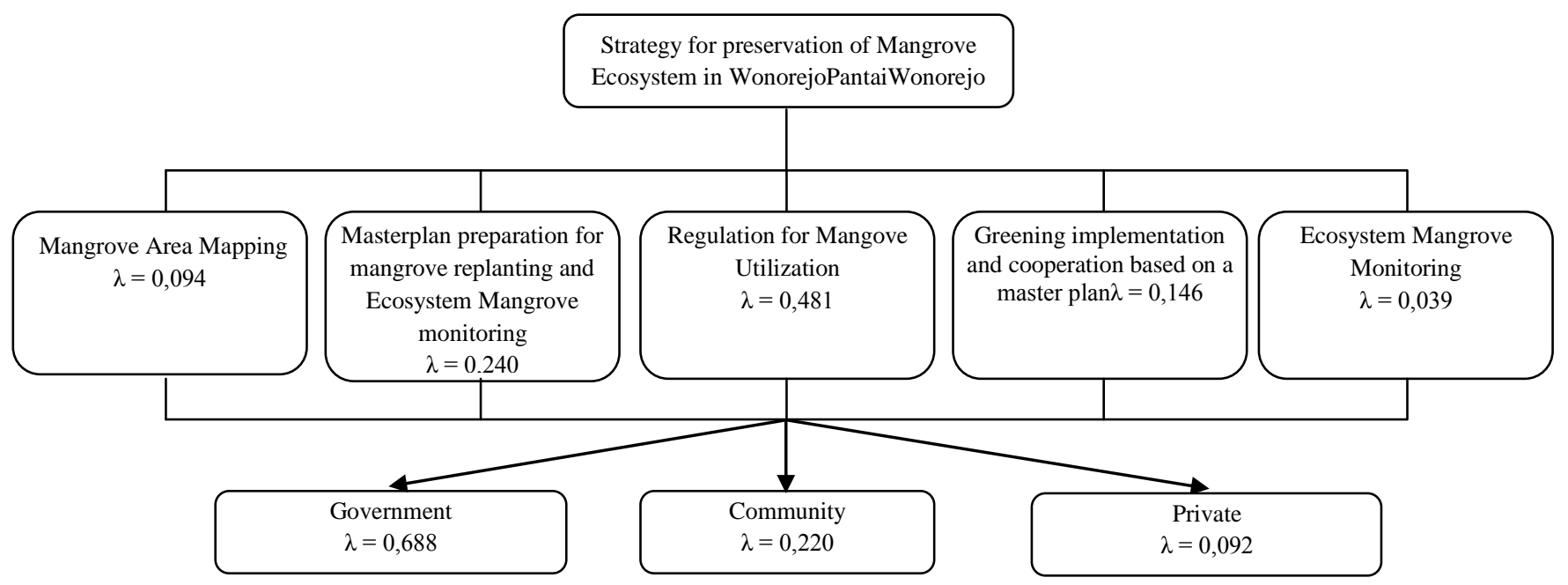

Fig 3.Prioritizing hierarchy Mangrove Ecosystem Conservation Strategy on the coast of Wonorejo

Based on the hierarchy of the above analysis, it was shown that in the prioritization of coastal mangrove ecosystem restoration and preservation strategies of Wonorejo based on five strategic priorities as described in the chart hierarchy. The fifth strategy has eigenvalue or weight of different priorities. Eigen highest value owned by the strategy drafting rules and regulations governing the use of mangrove. The second highest eigenvalue owned by the strategy of developing a master plan for replanting and Mangrove ecosystem monitoring. From the results of the

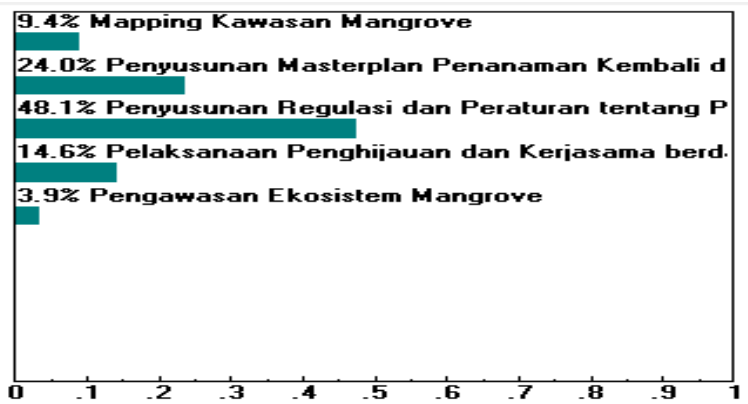

Fig 4. Strategy priority in preserving mangrove ecosystem in Wonorejo analysis indicated that the strategic priorities in the conservation of mangrove ecosystems Wonorejo shore focused on the planning process. This indicates that the mangrove rehabilitation activities in the region of Wonorejo is not well planned and it is not encouraged people participation optimally.

The test results of strategic priorities in addressing the problems in the mangrove rehabilitation Wonorejo coast region can also be explained in the following graph:

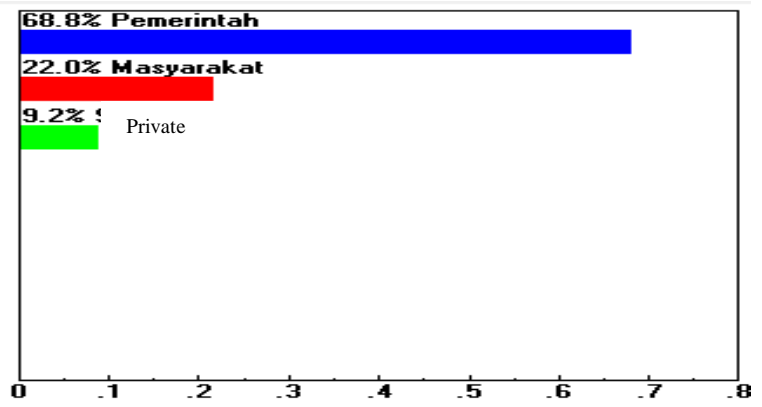


Based on the priority chart above, it can be explained that the key strategy in addressing issues of preservation of the mangrove ecosystem is drafting rules and regulations governing the use of mangrove with priority weighting of $48.1 \%$. Priority parties involved in addressing the problems of preservation of mangrove ecosystem Wonorejo beach area is government priority with a weight of $68.8 \%$. While the second priority is the community with the priority weighting of $22 \%$. If it is explore more head to head with charts, graphs obtained as follows:

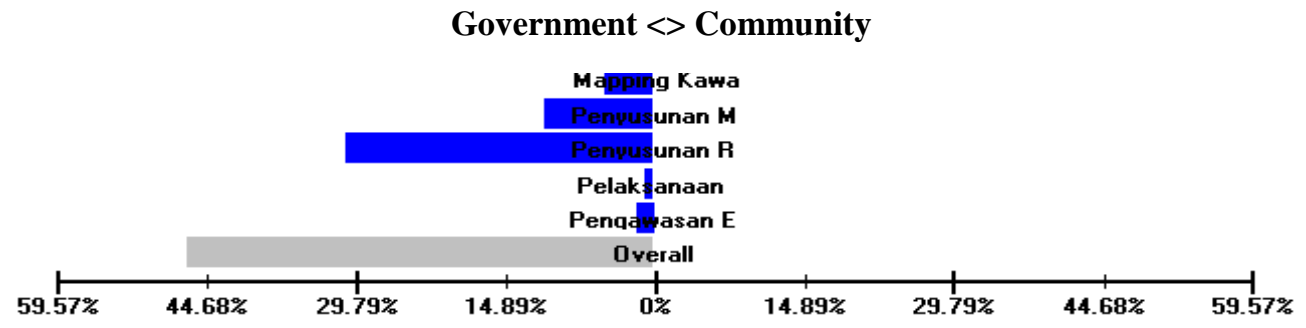

Fig 5. Head to head between the role of government with community

Based on the chart above, it can be inferred that the role of government is very dominant to restore and to reserve the mangrove forest. Nevertheless, the government realized that they can not work alone to implement mangrove restoration program. They need local people and private to work together. The government must take a lead in the planning, implementing and monitoring and evaluating of mangrove restoration and preservation. In addition, government of Surabaya is encouraged to provide socialization and training for local people and private to be more environmentally responsible homes, especially in mangrove ecosystem. Thus, the public participation was essential to participate in the restoration of mangrove. To establish a program of restoration, rehabilitation and conservation of mangrove forests, the Surabaya government should encourage local communities and the private sector to participate and work together. For that we need a forum with representatives of the elements of society, the private sector and government. To strengthen and empower the forum, it was necessary to build the capacity building program that includes training, education, assistance mangrove seeds, full authority to rehabilitate, restore and conserve mangrove in the form of a decree from the government of the city of Surabaya.

Participation is defined as "to have a share in" or "to take part in," thereby emphasizing the rights of individuals and the choices that they make in order to participate. Arnstein (1969) states that the idea of citizen participation is a little like eating spinach: no one is against it in principle because it is good for you. But there has been little analysis of the content of citizen participation, its definition, and its relationship to social imperatives such as social structure, social interaction, and the social context where it takes place. Awareness and understanding have grown leading to more realistic and compatible attitudes and expectations. As stated by Erftemeijer et.al (2009) that the project has taken a flexible and open approach putting considerable effort into the creation of a strong sense of local ownership of the process and allowing them to play a major role in the planning and decision-making of the project. This has demonstrated clearly to the community that their concerns and ideas are taken seriously. Thus, at the same time, it is strengthening local community trust in the participatory process. Nevertheless, the public trust must be strengthened with the clarity of the strategic plan that will guide the joint work between the representatives of the forum members. The strategic plan provides a clear vision and mission, and it has a value and a clear program and activities.

Referring to Bergquist, D.A (2007) stated that Factors affecting economic viability, social equity and environmental impacts in aquaculture is discussed and it is used to illuminate local and regional differences. To build a sustainable participation in the forum, then it needed the government's commitment of Surabaya through village government. The main program refers to the strategic plan that has been prepared by the forum. The programs covers economic, social and environment to empower institution as local institution.

The main focus of activities is how the forum together with the rehabilitation and restoration of mangroves to make more dense mangrove forests to plant mangrove species in accordance with the original species. Forum should avoid planting mangrove species that are not native species. According to Lewis (1992) that the mangrove habitat can improve their condition naturally within 15-30 years if: a) normal hydrology is not disrupted, and b) the availability of fruit and mangrove seedlings as well as the distance is not disrupted or blocked. If hydrology normal or near normal, but can not reach the fruit mangrove restoration area, the mangrove can be restored by planting. Because the mangrove habitat can be improved without planting, restoration plans must first look at the potential for unobstructed flow of sea water or 
other environmental pressures that may hinder the development of mangrove. Forum need to observe the course of the water. If the water flow is blocked and there are other pressures, it must be treated first by the forum. If not, or if it has been handled, then it is done observation to determine whether there growth. Forum will assist natural recovery through planting only if natural recruitment does not occur.

Forum should note that many projects of rehabilitation and restoration of mangrove planting directly without considering why growth does not occur naturally. Capital is often issued by the government and society for mangrove seedlings in a nursery and to plant restoration before stress factors are identified and addressed. This often ends in failure. Forum should also note that the planting of mangrove species should be based on the species of mangrove. Research Tam and Wong (1996) which says that the ability to accumulate heavy metals is different for each species of mangrove. Mangroves accumulate heavy metals was found in the roots. However, other factors such as mobility and solubility of metal also affects the accumulation of heavy metals in plants. Forum needs to know that the type of Avicennia marina mangrove species have the ability phytoremediation in tackling toxic. This was done to weaken the toxic effect through dilution. That is done by saving a lot of water to dilute the concentration of heavy metals in the body tissue so as to reduce the toxicity of the metal. Dilution with water storage in the tissue usually occurs on the leaves and followed by thickening of the leaf.

Based on the above results, it can be concluded as follows: (1). The role of work together among government-private- local community in one forum as the key to success ; (2) the role of such forum need to be institutionalized functional and serves as a non-governmental organization; (3) the government remains strongly intervened in the planning, implementation, monitoring and evaluation; (4). The village head had to issue the village head of the community to implement forum as local institutional body; (5) any consequences as a result of the issuance of the decree the head of the village, it should be allocated operational funds for coastal rehabilitation and restoration from planning, implementation, monitoring and evaluation.

\section{CONCLUSION}

Based on the chart head to head as shown above, if the role of the community in comparison to the role of government, the most important role for the restoration of mangrove destruction is the role of government. Although the dominant role of the government, but the government realized can not walk alone implement mangrove restoration program, if not supported by the public role. This shows that the government must take the lead in the implementation of mangrove rehabilitation. The government must work extra hard and be the main actor in all aspects of mangrove rehabilitation, both in the preparation, planning, implementation, and monitoring the rehabilitation of mangrove forests. In addition, governments are encouraged to provide socialization and training for local people to be more environmentally responsible homes, especially in the mangrove ecosystem. Thus the public participation was essential to participate in the restoration of mangrove. To avoid in order to avoid false public participation, the participation of society, including private and public roles be in one forum. The forum was legalized in the form of a decree village head.

\section{REFERENCES}

[1] Adiwijaya, Hendra. (2012), “Condition of Surabaya mangrove east coast and its impact on the environment", Environmental IlmiahTeknik Journal, Volume 1. Special Edition.

[2] Arnstein's Ladder, (1969), "Degrees of Citizen Participation", Journal of the American Planning Association, Vol. 35, No. 4, July 1969, pp. 216224

[3] Bergquist, D.A., (2007), "Sustainability and local people's participation in coastal aquaculture: Regional differences and historical experiences and historical experiences and historical experiences in Sri lanka and the Philippines", Environmental Management (2007) 40: 787. doi:10.1007/s00267-006-0108-y

[4] Environment Agency Surabaya, (2012), "The profile of biodiversity in Surabaya in 2012", The book Profile BLH Surabaya.

[5] Erftemeijer, Paul and Pieter Teunissen, (2009), "ICZM plan Surinamemangrove report: Analysis of problem and solutions for the management of mangrove forests along Suriname's wild coast", Fina reports. Lievense Deltares. September 2009.

[6] Erftemeijer, P.L.A and A. Bualuang., "Participation of Local Communities in Mangrove Forest Rehabilitation in Pattani Bay, Thailand: learning From Successes and Failure", Strategies for wise use of wetlands: Best practices of in participatory management.

[7] Jaya, I GedeNyoman Mindra., I Made Sumertajaya., (2008), "Structural equation modeling with partial least square", National Seminar on Mathematics and Mathematics education, Bogor.

[8] Jogiyanto and Abdillah, (2009), "Concepts and Applications First PLS For Research Empiris", Edisi, BPFE-Yogyakarta.

[9] Lewis, R. R. (1992). "Coastal habitat restoration as a fishery management tool." Stemming the tide of coastal fish habitat loss. Proceedings of a Symposium on Conservation of Coastal Fish Habitat, Baltimore, MD, 7-9 March1991. R. H. Stroud, ed., National Coalition for Marine Conservation, Inc., Savannah, GA, 169-173.

[10] Mikkelsen, Britha., (2003), "Participatory research methods and empowerment efforts: a handbook for practitioners of the field", Matheos translation Nalle, Jakarta: Yayasan Obor Indonesia.

[11] Surabaya Regional Regulation No. 3 of 2007 on Spatial Planning Surabaya. City Government of Surabaya.

[12] Saaty, T. Lorie, (1993), "Decision making for leaders, analytic hierarchy process for decision making in complex situations", Pustaka Binama Pressindo.

[13] Tam , N N. F. Y. dan Wong, Y.S., 1996, "Retention and Distribution of Heavy Metals in Mangrove Soils Receiving Wastewater", Environmental Pollution, 94 (3) : 283-291

[14] Wahwakhi, Salmana, (2015), “Assessment of Avicennia Alba as Agent Phytoremediation Efforts Reducing the concentration of Pb Heavy Metals in Mangrove ecosystem KelurahanWonorejo", Surabaya. Thesis Marine Science Program, Department of Fisheries Resource Utilization and Marine Sciences,Malang.

[15] Wijanarko, Bambang., (2006), "Possible application of co-management in the management of green open space on the north coast city of Surabaya", Engineering master's thesis study program development region and the city, Semarang.

[16] Wells, M. and Brandon, K., (1992), "People and Parks. Linking Protected Area Management with Local Communities", World Bank, WWF-US and US-AID, Washington. 